\title{
Protein kinase CK2 and ion channels (Review)
}

\author{
MATHIAS MONTENARH and CLAUDIA GÖTZ \\ Medical Biochemistry and Molecular Biology, Saarland University, D-66424 Homburg, Saarland, Germany
}

Received May 26, 2020; Accepted July 28, 2020

DOI: $10.3892 /$ br.2020.1362

\begin{abstract}
Protein kinase CK2 appears as a tetramer or higher molecular weight oligomer composed of catalytic CK $2 \alpha$, $\mathrm{CK} 2 \alpha^{\prime}$ subunits and non-catalytic regulatory CK2 $\beta$ subunits or as individual subunits. It is implicated in a variety of different regulatory processes, such as Akt signalling, splicing and DNA repair within eukaryotic cells. The present review evaluates the influence of CK2 on ion channels in the plasma membrane. CK2 phosphorylates platform proteins such as calmodulin and ankyrin $\mathrm{G}$, which bind to channel proteins for a physiological transport to and positioning into the membrane. In addition, CK2 directly phosphorylates a variety of channel proteins directly to regulate opening and closing of the channels. Thus, modulation of CK 2 activities by specific inhibitors, by siRNA technology or by CRISPR/Cas technology has an influence on intracellular ion concentrations and thereby on cellular signalling. The physiological regulation of the intracellular ion concentration is important for cell survival and correct intracellular signalling. Disturbance of this regulation results in a variety of different diseases including epilepsy, heart failure, cystic fibrosis and diabetes. Therefore, these effects should be considered when using CK2 inhibition as a treatment option for cancer.
\end{abstract}

\section{Contents}

1. Introduction

2. CK2 and sodium channels

3. CK2 and potassium channels

4. CK2 and calcium channels

5. CK2 and anion channels

6. Conclusion

Correspondence to: Professor Mathias Montenarh, Medical Biochemistry and Molecular Biology, Saarland University, Building 44, D-66424 Homburg, Saarland, Germany

E-mail: m.montenarh@mx.uni-saarland.de

Key words: protein kinase CK2, ion channels, phosphorylation, review, protein- protein interaction

\section{Introduction}

Genes for 122 protein kinases have been identified in yeast cells, 540 in mice and 518 genes in the human genome (1). One of these protein kinases is protein kinase CK2, formerly known as casein kinase 2, which is a ubiquitously expressed, constitutively active serine/threonine and tyrosine kinase (2). In total, more than 500 protein substrates have been identified and CK2 is estimated to be responsible for up to $10 \%$ of the human phosphoproteome $(3,4)$. CK 2 is a soluble, readily extractable form in all eukaryotic cells. Moreover, Burnett and Kennedy (5) purified the soluble kinase activity from rat liver and named the enzyme according to 'casein', which was used as a substrate to analyse the kinase activity.

The CK2 holoenzyme is a tetramer, comprised of two catalytic $\alpha$ - or $\alpha^{\prime}$ - and two non-catalytic $\beta$-subunits (6). The $\alpha$-subunits are encoded by two distinct homologous genes, CSNK2A1 which encodes CK2 $\alpha$ (7) and CSNK2A2 which encodes CK2 $\alpha^{\prime}$ (8). The $\beta$-subunit is encoded by CSNK2B (9). $\mathrm{CK} 2 \beta$ is not a simple on-off regulator of the catalytic activity of CK $2 \alpha$. It regulates thermostability, substrate specificity and the ability to attach and penetrate cell membranes (10-13). In addition to the tetramer, higher molecular weight forms of CK2 have been identified $(14,15)$. Although the CK2 tetramer has a dissociation constant of around $4 \mathrm{nM}(16,17)$ suggesting a permanent or a strong transient hetero complex, there is increasing evidence that the catalytic $\mathrm{CK} 2 \alpha$ subunits exist in the absence of CK2 $\beta$ (18) and that CK2 $\beta$ exists in the absence of CK $2 \alpha$ and CK2 $\alpha^{\prime}(19,20)$.

$\mathrm{CK} 2 \alpha$ is known to have oncogenic potential (21). While no germline mutations in any of the CK2 genes have been described, patients with somatic mutations in the CSNK2A1 gene coding for CK $2 \alpha$ have been identified (22). These patients suffered from intellectual disability, hypotonia, speech problems, gastrointestinal problems and immune dysfunctions (23-25).

CK $2 \alpha$ and CK2 $\beta$ are essential for embryonic development. For instance, mortality occurs in CK $2 \alpha^{-/-}$embryos in mid-gestation, with defects in heart and neural tube (26). CK $2 \beta^{-/-}$mice die shortly after implantation with no signs of apoptosis but reduced cell proliferation. Furthermore, CK $2 \beta^{-/-}$ blastocysts cannot develop an inner cell mass in vitro (27). It has also been revealed that CK $2 \alpha^{\prime}$ knockout mice are viable but the male knockout mice exhibit globozoospermia (28). A recent review summarizes the knowledge about the role of CK2 in development and differentiation (29). 
CK2 can use ATP as well as GTP as phosphate donor $(30,31)$. Although CK2 is not responsible for the regulation of a single particular pathway, it can regulate various signalling pathways including NFאB pathway, STAT3-, PTEN/PI3K/Akt- and the Wnt/ $\beta$-catenin pathway (32-37). In addition, CK2 may be involved in the regulation of stress- elicited pathways, such as proteotoxic stress, unfolded protein response and DNA damage pathways $(38,39)$. It has previously been reported that the kinase activity of CK2 is elevated in rapidly proliferating cells and in particular in tumour cells (21). Multiple attempts have been conducted to develop inhibitors for the CK2 kinase activity (40-43) including the use of small organic compounds such as 5-3-chlorophenylamino)benzo[c][2,6]naphthyridine-8caboxylic acid(CX-4945),4,5,6,7-tetrabromo-1H-benzotriazole (TBB), 5,6-dichloro-1-beta-D-ribofuranosylbenz-imidazole (DRB),2-dimethylamino-4,5,6,7-tetrabromo-1H-benzimidazole (DMAT), 5,6-dihydro-5-oxo-indolo-[1,2-a]-quinazoline-7acetic acid (IQA), 1,3,8-trihydroxy-6-methylanthracene-9,10-dione (emodin) and a whole group of flavonoids, which can target the ATP binding site on the catalytic CK $2 \alpha$ or CK $2 \alpha^{\prime}$ subunits (44-50). CX-4945 has been tested on more than 145 kinases and is demonstrated to be highly specific for CK2 and effective at micromolar concentrations (50). Recently, it was reported that CX-4945 also strongly inhibits cdc2 like kinases (51). Despite the large influence of CK2 on the human phosphoproteome, CX-4945 has been well tolerated in phase I clinical trials, (for example multiple myeloma clinical trial no. NT01199718), reviewed in (52).

CK2 is ubiquitously scattered within eukaryotic cells (53-56) and is present on the cell surface as an ecto-kinase (57). Moreover, CK2 is located in lipid rafts of brain synaptosomes and uterine cell membranes $(58,59)$. In brain synaptosomes, inhibition of CK2 resulted in an enhanced neurotransmitter release (59). There is increasing evidence that CK2 phosphorylates numerous ion channels located within membranes. The present review evaluated ion channels in the plasma membrane as substrates or binding partners of CK2.

\section{CK2 and sodium channels}

There are two major classes of sodium channels in mammals known as the voltage gated sodium channels (VGSCs, $\mathrm{Na}_{\mathrm{v}}$ ) and the epithelial sodium channels (ESCs) (60). A major physiological role for VGSCs is the generation of action potentials at the axonal initial segments (AIS) and in myelinated axons $(61,62)$. The generation and propagation of action potentials requires the precise accumulation of the voltage-gated sodium channels, such as $\mathrm{Na}_{\mathrm{v}} 1.1, \mathrm{Na}_{\mathrm{v}} 1.2$ and $\mathrm{Na}_{\mathrm{v}} 1.6$ at the AIS and in the nodes of Ranvier, which is achieved via ankyrin $G$ scaffolding (Fig. 1A). It has been observed that the large intracellular domain of the VGSCs contains a highly conserved ankyrin $\mathrm{G}$ binding motif. However, the binding motif for the $\mathrm{Na}_{\mathrm{v}} \mathrm{s}$ is also highly conserved on the polypeptide chain of ankyrin $\mathrm{G}(63,64)$. Brachet et al $(62)$ reported that CK2 phosphorylates the ankyrin $\mathrm{G}$ binding motif on the polypeptide chain of $\mathrm{Na}_{\mathrm{v}} 1$ (Fig. 1A). Moreover, mutation of the CK2 phosphorylation site on $\mathrm{Na}_{\mathrm{v}} 1$ to a non-phosphorylatable alanine abrogated the $\mathrm{Na}_{\mathrm{v}} 1$ /ankyrin $\mathrm{G}$ interaction. This mutation, as well as the use of the CK2 kinase inhibitor DMAT, leads to a decrease of $\mathrm{Na}_{\mathrm{v}} 1$ at AIS (62). Thus, CK2 may be involved in the modulation of $\mathrm{Na}_{\mathrm{v}} 1$ binding to ankyrin $\mathrm{G}$ as well as the accumulation of $\mathrm{Na}_{\mathrm{v}} 1$ at AIS at least in young neurons. In agreement with these observations, CK2 is enriched in AIS and nodes of Ranvier (65).

Amiloride-sensitive epithelial sodium channels (ENaCs) mediate the transport of $\mathrm{Na}^{+}$ions across membranes of epithelial cells and are composed of $\alpha, \beta$ and $\gamma$ subunits or $\delta, \beta$ and $\gamma$ subunits (66). Alterations in the composition of the $\mathrm{ENaCs}$ are responsible for differences in conductance, open probability, sensitivity to amiloride, and sensitivity to extra-cellular protons (66). The activity of $\mathrm{ENaC}$ is regulated by various protein kinases such as protein kinase A (PKA), PKC, ERK1/2 and CK2 (67). CK2 phosphorylates the $\mathrm{ENaC} \beta$ subunit at serine 631 and the $\gamma$ subunit at threonine 599 (68). Inhibition of the CK2 kinase activity as well as the use of ENaC subunits, in which both $\mathrm{CK} 2$ sites were mutated, demonstrates a reduced amiloride sensitive $\mathrm{Na}^{+}$transport (69). Furthermore, it was shown that CK2 directly binds to $\mathrm{ENaC}(68)$ and $\mathrm{CK} 2$ is transported to the cell membrane by wild-type $\mathrm{ENaC}$, but not by $\mathrm{ENaC}$, in which both $\mathrm{CK} 2$ phosphorylation sites are mutated (69). Regulation of ENaC by signalling molecules including hormones is critical for the regulation of electrolyte and water excretion and consequently for the regulation of blood pressure (70). Recently, the influence of $\mathrm{CK} 2$ on $\mathrm{ENaC}$ and sodium excretion was analysed in living organisms. For instance, Berman et al found that inhibition of CK2 kinase activity leads to a significant decrease in ENaC activity and natriuresis in mice. These results demonstrate that an appropriate regulation of $\mathrm{ENaC}$ by $\mathrm{CK} 2$ is necessary for fine regulation of the sodium concentration (71).

\section{CK2 and potassium channels}

The largest group of potassium channels are the voltage-gated channels known as $\mathrm{K}_{\mathrm{v}}$ channels (72). While ligand activated potassium channels also exist, their interaction with $\mathrm{CK} 2$ is yet to be elucidated. Similar to $\mathrm{Na}_{\mathrm{v}} \mathrm{s}, \mathrm{K}_{\mathrm{v}} \mathrm{s}$ are located in different parts of the AIS and carry an ankyrin G binding site (73). Pharmacological inhibition of the CK2 kinase activity using TBB or tetrabromocinnamide acid (TBCA) prevents the distal redistribution of $\mathrm{K}_{\mathrm{v}} 7.3$ channels along the AIS (74). Although not directly analysed by Lezmy et al (74), according to their results, it was suggested, that $\mathrm{CK} 2$ phosphorylates $\mathrm{K}_{\mathrm{v}} 7.2 / 3$ to increase their affinity to ankyrin $\mathrm{G}$ (Fig. 1A). A possible explanation for these results is that inhibition of CK2 kinase activity may prevent the insertion of new $\mathrm{K}_{\mathrm{v}} 7.2 / 3$ into the AIS. Alternatively, or in addition, CK2 may phosphorylate calmodulin, which increases its interaction with the $\mathrm{K}_{\mathrm{v}} 7.2$ subunit, and is crucial for the aforementioned redistribution (Fig. 1B) (75).

The firing rate of neurons is generated by M-type $\mathrm{K}^{+}$current generated by channels that contain $\mathrm{K}_{\mathrm{v}} 7 / \mathrm{KCNQ}_{2}-5$ subunits (76). Physiological functioning of these channels is necessary to maintain physiological neuronal excitability, and dysfunction of these channels may result in neurological disorders such as epilepsy (77). The transport of the KCNQ2 channel from the endoplasmic reticulum to the plasma membrane is regulated by calmodulin. According to the aforementioned findings, CK2 


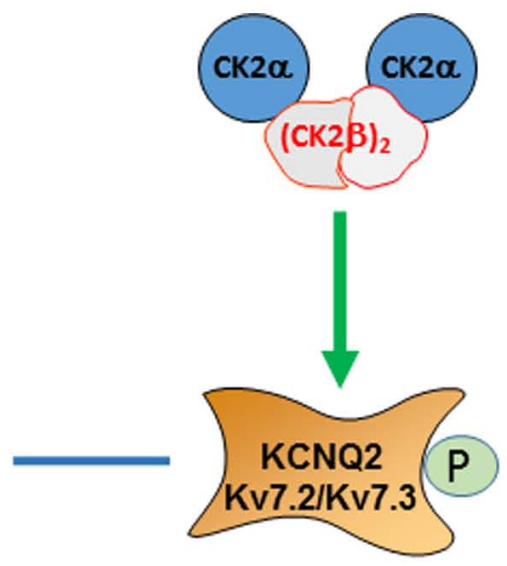

B

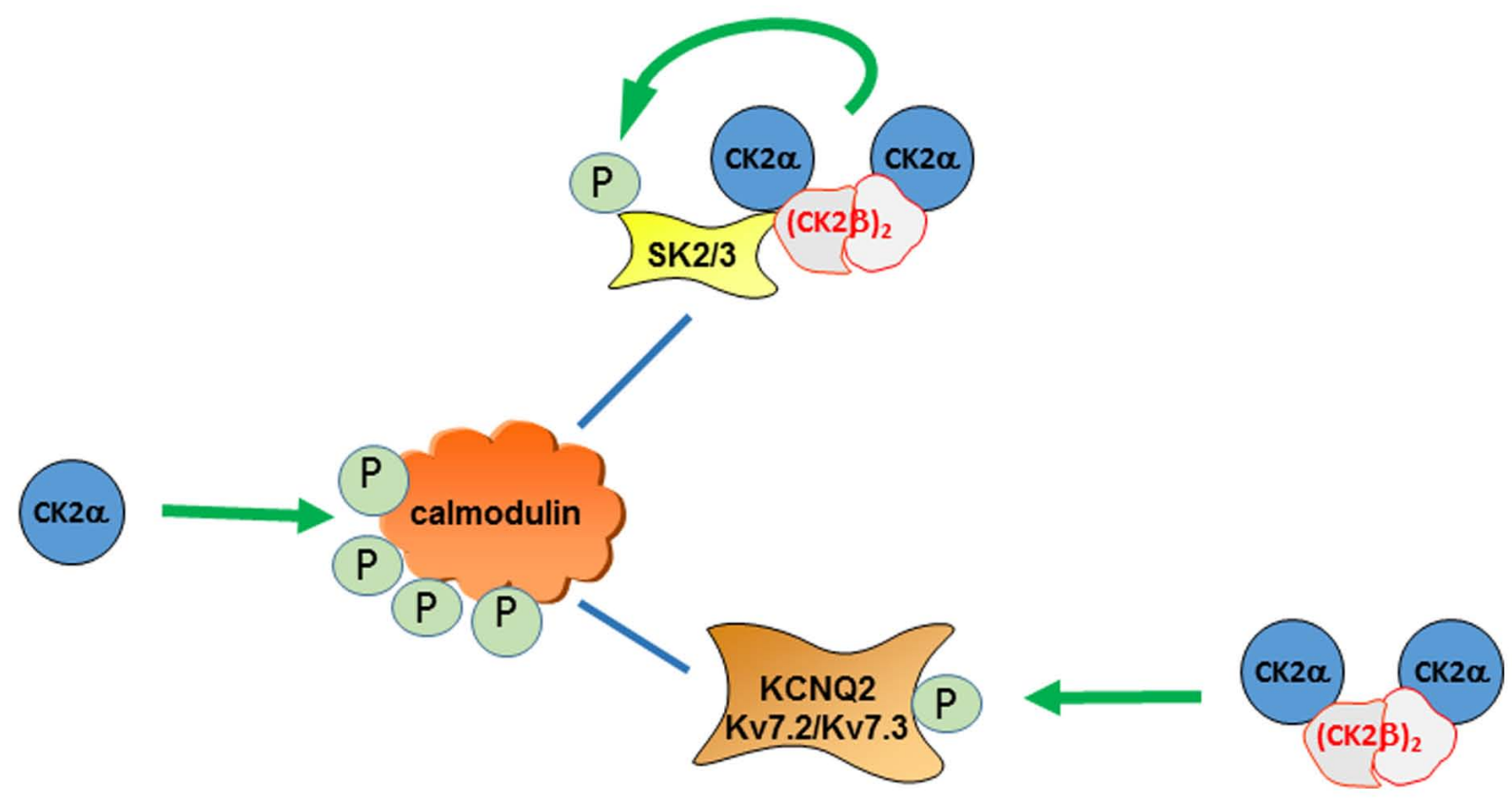

Figure 1. Influence of CK2 phosphorylation on binding of channel proteins to (A) ankyrin G or (B) calmodulin. Green arrows represent phosphorylation and interaction. Blue lines indicate an interaction. P, phosphate; CK2, casein kinase 2; SK, small conductance; KCNQ2, potassium voltage-gated channel subfamily Q member 2; Nav, sodium voltage-gated channels.

phosphorylation of KCNQ2 may be implicated in the transport of this channel to the plasma membrane. Moreover, the CK2 inhibitors TBB and TBCA have been used to study the interaction between ankyrin G and KCNQ2 and it was demonstrated that inhibition of CK2 kinase activity results in a reduced interaction of ankyrin G with KCNQ2 (Fig. 1A) (64,65,75). It has been observed that $\mathrm{CK} 2$, which accumulates at the AIS, phosphorylates calmodulin and thereby regulates the activity of KCNQ2. A previous study has also shown that ankyrin $\mathrm{G}$ binds stronger to $\mathrm{Na}_{\mathrm{v}} 1.2$ than to KCNQ2 (64).

A second family of potassium channels comprises the $\mathrm{Ca}^{2+}$ activated transmembrane potassium channels, which are divided into big-conductance (BK), small conductance (SK) and intermediate conductance channels. SK channels are widely expressed in the central nervous system and the cardiovascular system, and are structurally similar $\mathrm{K}_{\mathrm{v}} \mathrm{s}$. Gating of SK is achieved via the constitutive interaction between the pore-forming subunits and calmodulin. Binding and unbinding of $\mathrm{Ca}^{2+}$ ions to calmodulin are transduced via conformational changes in channel opening and closure, respectively (78). SK channels couple the membrane potential to fluctuation in the intracellular $\mathrm{Ca}^{2+}$ concentration. Each of the four SK $\alpha$-subunits harbours one bound calmodulin molecule (79). Moreover, calmodulin, which is phosphorylated by CK2 $(80,81)$ inhibits SK channels $(82-84)$. Calmodulin is phosphorylated by $\mathrm{CK} 2 \alpha$ but not by the holoenzyme consisting of CK $2 \alpha$ and CK $2 \beta$. CK 2 phosphorylation of calmodulin reduces the affinity of calmodulin for intracellular $\mathrm{Ca}^{2+}$ ions, which leads to a deactivation of the SK channel (82). Furthermore, this effect is reversed by protein phosphatase 2A (PP2A), which dephosphorylates calmodulin leading to a recovery of the $\mathrm{Ca}^{2+}$ binding affinity of calmodulin and thereby to a recovery of the channel activity (84).

SK 2 channel phosphorylation by CK 2 results in a deactivation of the channel, while dephosphorylation has the reverse effect (83). Allen et al (84) and Bildl et al (83) reported, that both CK $2 \alpha$ and CK2 $\beta$ and PP2A bind to the cytoplasmic N-and 
C-termini of SK channels to form a multiprotein complex at the plasma membrane of rat brains. Furthermore, PP2A binds to a region on the polypeptide chain of SK, which was previously identified as the PP2A binding site on the polypeptide chain of SV40 small T antigen and CK $2 \alpha(18,85)$. Positively charged compounds, such as spermine or poly-L-lysine, are known to stimulate the kinase activity of CK2 (79). The $\mathrm{N}$-terminal domain of SK2 contains a cluster of positively charged residues close to the site of interaction with CK $2 \alpha$ and it was revealed that this region stimulated CK2 similar to poly-L-lysine (84). Within this complex, CK2 phosphorylates calmodulin, thereby reducing the $\mathrm{Ca}^{2+}$ sensitivity and accelerating channel deactivation (86).

Neurotransmitters, such as noradrenalin, inhibit SK2 channels independently of changes in the activity of the priming $\mathrm{Ca}^{2+}$ channels (82). In total, there are three homologous SK channels, namely SK1-3, expressed in the mammalian brain (87). Inhibition of CK2 by TBB or the use of a dominant-negative $\mathrm{CK} 2 \alpha \mathrm{K} 68 \mathrm{M}$ mutant strongly reduces the effect of noradrenalin on SK channels (82). However, the signalling pathway from the activated receptor to $\mathrm{CK} 2$ awaits further analysis.

The influence of CK2 and potassium channels in disease is yet to be fully elucidated. However, it has been shown that increased expression of CK2 in the infarct border is associated with reduced SK1/Kir2.1 protein levels (88). Furthermore, overexpression of $\mathrm{CK} 2$ suppressed the KCNJ2/Kir2.1 expression and inhibition of CK2 kinase activity enhanced KCNJ2/Kir2.1 expression (89). It has been shown that hypoxia leads to increased CK2 expression in the heart of male Wistar rats, and the CK2/Kir2.1 pathway may be a potential therapeutic target for ventricular arrhythmias (vAs) after myocardial infarction (89). CK2 phosphorylates the transcription factor SP1, which regulates the expression of the potassium inwardly rectifying channel subfamily $\mathrm{J}$ member 2 gene, encoding Kir2.1. The angiotensin 1 receptor antagonist valsartan reduces CK2 activation at the infarct border and increases Kir2.1 expression (89). These findings provide an insight into the pathophysiological molecular mechanisms which occur following myocardial infarction, and in particular, into the role of $\mathrm{CK} 2$ in this process.

The $\mathrm{K}_{\mathrm{Ca}} 2.2$ channel represents the major isoform of voltage small conductance $\mathrm{Ca}^{2+}$ activated $\mathrm{K}^{+}$channels in the hippocampus (90). The $\mathrm{K}_{\mathrm{Ca}} 2.2$ channel is phosphorylated by CK2 $(83,84)$ and gated by the intracellular assembly with calmodulin (91). CK2 phosphorylation leads to an impairment of the $\mathrm{K}_{\mathrm{Ca}} 2.2$ channel activity. Previously, in a rat pilocarpine epilepsy model, it was reported that oral administration of the CK2 kinase inhibitor TBB enhances $\mathrm{K}^{+}$currents and it blocks the occurrence of spontaneous epileptic activity (92). TBB also enhances the $\mathrm{K}_{\mathrm{Ca}} 2.2$ protein level in the Cornus Ammonis (CA1) region from post status epilepticus (93). Moreover, there is a reduced expression of CK2 proteins in CA1 of epileptic animals (94). The mechanism for the reduced abundance of CK2 proteins remains to be elucidated.

\section{CK2 and calcium channels}

$\mathrm{Ca}^{2+}$ ions are essential for nearly all aspects of cell functions. $\mathrm{Ca}^{2+}$ channels in the plasma membrane play an important role in controlling intracellular calcium homeostasis (95). Recently, Afzal et al revealed that inhibition of CK2 with high concentrations of TBB leads to a considerable loss of total cellular $\mathrm{Ca}^{+}$in prostate cancer cells. In addition, inhibition of CK2 results in a decrease of cytosolic $\mathrm{Ca}^{2+}$ levels, along with an increase in mitochondrial and endoplasmic levels of $\mathrm{Ca}^{2+}$ in these cells (96). Thus, these results indicate CK2 may be involved in the regulation of the intracellular $\mathrm{Ca}^{2+}$ homeostasis.

$\mathrm{Ca}^{2+}$ channels include voltage-gated $\left(\mathrm{Ca}_{\mathrm{v}}\right)$ and ligand-gated channels. Voltage-gated channels $\left(\mathrm{Ca}_{\mathrm{v}}\right)$ channels are sub-divided into L-type $\left(\mathrm{Ca}_{\mathrm{v}} 1.1-\mathrm{Ca}_{\mathrm{v}} 1.4\right), \mathrm{P} / \mathrm{Q}$-type $\left(\mathrm{Ca}_{\mathrm{v}} 2.1\right)$, $\mathrm{N}$-type $\left(\mathrm{Ca}_{\mathrm{v}} 2.2\right)$, R-type $\left(\mathrm{Ca}_{\mathrm{v}} 2.3\right)$ and T-type $\left(\mathrm{Ca}_{\mathrm{v}} 3.1-\mathrm{Ca}_{\mathrm{v}} 3.3\right)$ channels, while the ligand-gated channels include IP3-receptor type, ryanodine receptor type, store operated channels amongst others (97-100).

In response to membrane depolarization the conformation of $\mathrm{Ca}_{\mathrm{v}}$ channels switches from a close to an open state, and $\mathrm{Ca}^{2+}$ influx via $\mathrm{Ca}_{\mathrm{v}}$ channels serves as a second messenger to couple electric signalling to chemical signalling $(99,100)$. The $\mathrm{Ca}^{2+}$ concentration controls a diverse range of intracellular events such as endocytosis, exocytosis, muscle contraction, synaptic transmission and metabolism (101) thus controlling proliferation, differentiation and development. $\mathrm{Ca}_{\mathrm{v}}$ channels share a common subunit composition, where $\mathrm{Ca}_{\mathrm{v}} \alpha 1$ subunits are pore forming, and $\mathrm{Ca}_{\mathrm{v}} \beta$ and $\mathrm{Ca}_{\mathrm{v}} \delta$ as well as in some cases $\mathrm{Ca}_{\mathrm{v}} \gamma$, are ancillary subunits (99). The $\alpha_{1}$ subunit is composed of four homologous transmembrane domains and cytoplasmic $\mathrm{N}$ - and C-termini. In addition to these subunits, calmodulin is also present in these complexes (102).

The L-type calcium current is critical for the development, function and regulation of many different cell types including physiologic functions of nerve and muscle cells (103). L-type calcium channels are implicated in the excitation-contraction coupling in cardiac, skeletal and smooth muscle, in the regulation of $\mathrm{Ca}^{2+}$ homeostasis and secretion, tissue development, neuron excitability, excitation-transcription coupling and in learning and memory in the brain, reviewed in (104). Furthermore, L-type $\mathrm{Ca}^{2+}$ channel activation results in uterine contraction of mice, the activation of which is suppressed by inhibition of CK2 (58). $\mathrm{Ca}_{\mathrm{v}} 1.1$ is the L-type $\mathrm{Ca}^{2+}$ channel present in the skeletal muscle and $\mathrm{Ca}_{\mathrm{v}} 1.2$ is the L-type channel present in the heart. Both of these channels are regulated via phosphorylation by a number of different protein kinases, such as PKA, Akt, PKC and CK2 (103). Multiple regulatory sites are located in the large C-terminal domain of $\mathrm{Ca}_{\mathrm{v}} 1.1$ and $\mathrm{Ca}_{\mathrm{v}} 1.2$ channels (105-107). For instance, the PKA phosphorylation site at serine 1700 was required for the stimulation of channel activity (108), while threonine 1704 phosphorylation by CK2 is necessary for the regulation of basal channel activity. Mice with mutations at these two phosphorylation sites have a significantly reduced basal L-type calcium current and a reduced response to $\beta$-adrenergic stimulation $(109,110)$. In addition these mutant mice have an impaired contractile function, decreased exercise capacity and cardiac hypertrophy $(109,110)$.

The L-type $\mathrm{Ca}^{2+}$ channel $\mathrm{Ca}_{\mathrm{v}} 1.2$ regulates $\mathrm{Ca}^{2+}$ influx and initiates the human heartbeat $(103,111)$. In immature but not mature, mouse cardiomyocytes, Kashihara et al (111) have shown that angiotensin II regulates $\mathrm{Ca}_{\mathrm{v}} 1.2$ via the angiotensin type 1 receptor and induces a signalling cascade involving $\beta$-arrestin 2 , which stimulates the tyrosine kinase src, thus 
phosphorylating $\mathrm{p} 27^{\mathrm{kip} 1}$. This phosphorylation prevents p2 $7^{\mathrm{kip} 1}$ from inhibiting the phosphorylation of a C-terminal fragment of $\mathrm{Ca}_{\mathrm{v}} 1.2$ by CK2 (111). It has been reported that unphosphorylated $\mathrm{p} 27^{\mathrm{kipl}}$ is one of the very few proteins that specifically inhibits CK2 $\alpha^{\prime}$ (112). Moreover, CK2 $\beta$ binds to $\mathrm{Ca}_{\mathrm{v}} 1.2$ and recruits p27 $7^{\mathrm{kip} 1}$ and $\mathrm{CK} 2 \alpha^{\prime}$ to the $\mathrm{Ca}_{\mathrm{v}} 1.2$ complex (111). However, it remains unknown whether CK2 $\alpha$ functions alone or as a holoenzyme consisting of CK2 $2 \alpha^{\prime}$ and CK2 $2 \beta$.

A C-terminal fragment of $\mathrm{Ca}_{\mathrm{v}} 1.2$ translocates to the nucleus and regulates transcription (113) of a variety of different genes, such as the gap junction protein $\mathrm{Cx} 31.1$, the axon guidance factor Netrin 4, the regulator of G-protein signalling RGS5 and the tight junction protein claudin19, which are implicated in neuronal signalling and excitability. This result suggested that $\mathrm{Ca}_{\mathrm{v}} 1.2$ has a dual function as a channel and as a transcription factor. However, it is yet to be analysed whether the $\mathrm{Ca}_{\mathrm{v}} 1.2 \mathrm{C}$-terminus remains associated with $\mathrm{CK} 2 \alpha^{\prime} / \mathrm{CK} 2 \beta$ after translocation to the nucleus. The mechanism that triggers the cleavage of the $\mathrm{C}$-terminus is also not fully understood. It has been revealed that adenosine triphosphate regulates at least the activity of guinea pig $\mathrm{Ca}_{\mathrm{v}} 1.2$ by direct binding to the channel in a dose dependent manner (114). In addition, as further studies have reported that calmodulin and $\mathrm{Ca}^{2+}$ regulate ATP binding activities, it was hypothesized that this channel-bound ATP is directly necessary as a phosphate donor for protein kinases, which phosphorylate $\mathrm{Ca}_{\mathrm{v}} 1.2$.

Modulation of $\mathrm{Ca}_{\mathrm{v}} 2.1$ channel activity serves a key role in inter-neuronal communication and synaptic plasticity as well as in the regulation of exocytosis of insulin from storage granules of the human pancreas especially at low glucose concentrations (115). $\mathrm{Ca}^{2+}$ influx via $\mathrm{Ca}_{\mathrm{v}} 2.1$ promotes channel inactivation (116). In a recent study we identified $\mathrm{Ca}_{\mathrm{v}} 2.1$ as a substrate and as a binding partner for CK2 (117). Inhibition of CK2 by CX-4945 enhances the intracellular $\mathrm{Ca}^{2+}$ level, which corresponds with an increase in insulin secretion from pancreatic $\beta$-cells (117). Moreover, quercetin is a potent inhibitor of $\mathrm{CK} 2$ at $\mathrm{IC}_{50}$ values $<1 \mu \mathrm{M}$ (118), which induces insulin secretion by direct activation of L-type calcium channels in pancreatic $\beta$-cells.

A transient $\mathrm{Ca}^{2+}$ micro-domain is essential for synaptic exocytosis leading to the fast release of neurotransmitters (119). $\mathrm{Ca}_{\mathrm{v}} 2.1$ is regulated by interaction with its $\beta$-subunit, by SNARE proteins binding to $\mathrm{Ca}_{\mathrm{v}} 2.1$, and by $\mathrm{Ca}^{2+}$ - calmodulin attached to the $\mathrm{C}$-terminal tail of the $\mathrm{Ca}_{\mathrm{v}} 2.1 \alpha 1 \mathrm{~A}$ subunit (120). As aforementioned, CK2 phosphorylates calmodulin $(80,81)$, but it has to be elucidated whether CK2 phosphorylation affects the calmodulin/ $\mathrm{Ca}_{v} 2.1$ interaction.

In total, at least two other proteins, including syntaxin-1 and synaptotagmin-1, specifically interact with $\mathrm{Ca}_{\mathrm{v}} 2.1$ channels by binding to a synaptic protein interaction site within an intracellular loop of the channel $(121,122)$. CK2 is present in the membrane micro-domains from rat brain nerve endings and it phosphorylates syntaxin- 1 at serine 14 as assessed using phospho-specific antibodies (59). This N-terminal segment of syntaxin-1 including the CK2 phosphorylation site is involved in direct protein-protein interactions and leads to alterations in the neurotransmitter release (59). Furthermore, it has been demonstrated that the CK2 phosphorylation of syntaxin-1 may play a role in the pathophysiology of schizophrenia (123). Therefore, these data might suggest a differential regulation of $\mathrm{Ca}_{\mathrm{v}} 2.1$ by CK2, where syntaxin- 1 and synaptotagmin-1 are phosphorylated by the CK2 holoenzyme while calmodulin is phosphorylated by CK2 $\alpha$ alone.

\section{CK2 and anion channels}

Chloride or bicarbonate are transported across membranes by complex membrane proteins called anion channels. The transport of chloride and bicarbonate ions results in alterations of the $\mathrm{pH}$ within cells and also in alterations in the transport of water (124). A reduction in chloride and bicarbonate concentrations leads to a disease called cystic fibrosis. The cystic fibrosis transmembrane conductance regulator (CFTR) is an example of an anion channel present in epithelial cells and is a member of the family of ATP binding cassette $(\mathrm{ABC})$ proteins $(125,126)$. The activity of CFTR is, in part regulated by the cAMP-dependent protein kinase PKA (126). In addition, CK2 is implicated in the regulation of CFTR (127-133). It has been reported that TBB treatment of Calu-3 cells resulted in a significant inhibition of the basolateral $\mathrm{Cl}^{-} / \mathrm{HCO}_{3}{ }^{-}$exchanger. Treatment with the more efficient and specific inhibitor CX-4945 completely abolishes $\mathrm{Cl}^{-} / \mathrm{HCO}_{3}{ }^{-}$exchanger activity.

Recently, it has been revealed that CK2 is required for the physiological expression of the $\mathrm{Ca}^{2+}$ activated $\mathrm{Cl}^{-}$channel anoctamin 1 (ANO1), previously known as TMEM16A, in the plasma membrane. ANO1 is stimulated via G-protein coupled receptors (134). Small interfering RNA knockdown of CK2 $\alpha^{\prime}$ or inhibition of the kinase activity by TBB or CX-4945 leads to a reduced expression in the plasma membrane and an inhibition of the whole cell current in airways epithelial cells (134). Furthermore, these treatments result in an inhibition of cell proliferation. However, it remains to be analysed whether CK2 $\alpha^{\prime}$ directly phosphorylates ANO1 alone or as a CK $\alpha^{\prime} / \mathrm{CK} 2 \beta$ holoenzyme and whether CK2 $\alpha$ might have the same effect.

CK2 is not only stimulatory for the functions of channels. It inhibits the lipid flippase ABCA1, which is a CFTR related protein (135). A total of three residues, threonine 1,242 , threonine 1,243 and serine 1,255 in the cytoplasmic part of ABCA1 have been identified as CK2 phosphorylation sites (135). Moreover, mutation analysis and the use of CK2 specific inhibitors has revealed that CK2 phosphorylation affects flippase activity, apolipoprotein AI and AII binding and phospholipid and cholesterol efflux $(80,135)$.

The cellular uptake of a wide range of endogenous and exogenous molecules including many clinically used drugs is mediated by solute carrier transporters (SLC), which are transmembrane proteins (136). SLC4A2 is another member of the $\mathrm{Cl}^{-} / \mathrm{HCO}_{3}{ }^{-}$exchanger in human airway epithelia cells, which is phosphorylated by CK2 and whose activity is reduced by inhibition of CK 2 by TBB or CX-4945 or by knockdown experiments, suggesting that CK2 may be a key regulator of trans-epithelial transport in human airways (137). However, it remains unknown whether CK2 regulates SLC4A2 directly or indirectly by regulating calmodulin. CK2 has also been shown to influence the activity of the nucleoside transporters SLC29A1 and SLC29A2, previously known as ENT1 and ENT2, respectively (138). 
Table I. CK2 phosphorylation of channel proteins.

\begin{tabular}{|c|c|c|c|}
\hline First author, year & Substrates of CK2 & Function & (Refs.) \\
\hline Brachet et al, 2010 & $\mathrm{Na}_{\mathrm{v}} 1$ & Interaction with ankyrin $G$ & $(62)$ \\
\hline Shi et al, 2002 & ENaC $\beta$-subunit and $\gamma$-subunit & Amiloride sensitive $\mathrm{Na}^{+}$transport & $(68)$ \\
\hline $\begin{array}{l}\text { Xu and Cooper, 2015; } \\
\text { Brechet et al, } 2008\end{array}$ & $\mathrm{~K}_{\mathrm{v}} 7.2 / 3$ & Distribution of $\mathrm{K}_{\mathrm{v}} 7.2 / 3$ along AIS & $(64,65)$ \\
\hline Zhang et al, 2014 & Calmodulin/SK & Regulation of SK channel activity & $(86)$ \\
\hline $\begin{array}{l}\text { Xu et al, 2020; Fuller et al, 2010; } \\
\text { Scheuer et al, } 2020\end{array}$ & $\mathrm{Ca}_{\mathrm{v}} 1.2, \mathrm{Ca}_{\mathrm{v}} 1.1, \mathrm{Ca}_{\mathrm{v}} 2.1$ & $\mathrm{Ca}^{2+}$ transport & $(103,108,117)$ \\
\hline Cesaro et al, 2013; Luz et al, 2011 & CFTR & Chloride/bicarbonate transport & $(127,128)$ \\
\hline Roosbeek et al, 2004 & ABCA1 & Regulation of flippase activity & (135) \\
\hline Ibrahim et al, 2017 & SLC4A2 & Chloride/bicarbonate transport & (137) \\
\hline Stolk et al, 2005 & SLC29A1, SLC29A2 & Nucleoside transport & (138) \\
\hline
\end{tabular}

CK2, protein kinase CK2; SK, small conductance; ENaC, Amiloride-sensitive epithelial sodium channels; $\mathrm{Ca}_{\mathrm{v}}$, $\mathrm{Ca}^{2+}$ voltage-gated channels; SLC4A2, solute carrier family 4 member $2 ; \mathrm{K}_{\mathrm{v}}$, potassium voltage-gated channels; CFTR, cystic fibrosis transmembrane conductance regulator; ABCA1, ATP binding cassette subfamily A member 1; AIS, axonal initial segments; $\mathrm{Na}_{\mathrm{v}}$, sodium voltage-gated channels.

Table II. Binding of CK2 to channel proteins.

\begin{tabular}{|c|c|c|c|}
\hline First author, year & CK2 binding partner & Function & (Refs.) \\
\hline Shi et al, 2002 & $\mathrm{ENaC}$ & Transport to the plasma membrane & (68) \\
\hline Bildl et al, 2004; Allen et al, 2007 & SK channels & $\begin{array}{l}\text { Formation of multi-protein complex at the plasma membrane } \\
\text { of rat brain increase of CK } 2 \text { kinase activity }\end{array}$ & $(83,84)$ \\
\hline Kashihara et al, 2017 & $\mathrm{Ca}_{\mathrm{v}} 1.2$ & Recruitment of p $27^{\text {kip } 1}$ and CK $2 \alpha^{\prime}$ to the membrane & (111) \\
\hline Scheuer et al, 2020 & $\mathrm{Ca}_{\mathrm{v}} 2.1$ & $\mathrm{Ca}^{2+}$ transport & (117) \\
\hline
\end{tabular}

CK2, protein kinase CK22; SK, small conductance; ENaC, Amiloride-sensitive epithelial sodium channels; $\mathrm{Ca}_{v}, \mathrm{Ca}^{2+}$ voltage-gated channels.

\section{Conclusion}

In conclusion, protein kinase CK2 is implicated in central cellular processes, such as regulation of cell proliferation, differentiation, RNA splicing, DNA repair and angiogenesis. The present review has summarized the knowledge regarding the regulation of cation and anion channels. This regulation is achieved either by direct phosphorylation of proteins building the channels (Table I) or via phosphorylation of platform proteins such as calmodulin and ankyrin G (Fig. 1), which are responsible for binding, transport and physiological orientation of channel proteins into the plasma membrane. In addition, CK2 subunits bind to certain proteins which compose the channels (Table II), which might reflect an enzyme /substrate interaction or a currently unknown function. Regulation of the intracellular ion concentration contributes to an altered membrane potential, which influences cellular excitability of a variety of different cell systems including neuronal and muscle cells. Moreover, the intracellular ion concentrations plays an important role in a variety of different conditions such as heart failure, epilepsy, cystic fibrosis and diabetes. These effects have been considered when $\mathrm{CK} 2$ inhibitors are used for the treatment of cancer. Furthermore, the knowledge of the role of CK2 in the regulation of ion channels in the plasma membrane may facilitate the targeting CK2 for the regulation of intracellular ion concentrations and ultimately cellular signalling.

\section{Acknowledgements}

Not applicable.

\section{Funding}

This work was supported by the Rolf M. Schwiete Stiftung, Mannheim, Germany (grant nos. 06/2015 and 2020-006).

\section{Availability of data and materials}

Not applicable.

\section{Authors' contributions}

MM and CG performed literature research, wrote the paper, and read and approved the final manuscript. 


\section{Ethics approval and consent to participate}

Not applicable.

\section{Patient consent for publication}

Not applicable.

\section{Competing interests}

The authors declare that they have no competing interests.

\section{References}

1. Manning G: Genomic overview of protein kinases. WormBook 1-19, 2005.

2. Litchfield DW: Protein kinase CK2: Structure, regulation and role in cellular decisions of life and death. Biochem J 369: 1-15, 2003.

3. Salvi M, Sarno S, Cesaro L, Nakamura $H$ and Pinna LA: Extraordinary pleiotropy of protein kinase CK2 revealed by weblogo phosphoproteome analysis. Biochim Biophys Acta 1793 847-859, 2009.

4. de Villavicencio-Diaz T, Rabalski AJ and Litchfield DW: Protein kinase CK2: Intricate relationships within regulatory cellular networks. Pharmaceuticals (Basel) 10: 27, 2017.

5. Burnett G and Kennedy EP: The enzymatic phosphorylation of proteins. J Biol Chem 211: 969-980, 1954.

6. Boldyreff B, Meggio F, Pinna LA and Issinger OG: Protein kinase CK2 structure-function relationship: Effects of the $\beta$ subunit on reconstitution and activity. Cell Mol Biol Res 40: 391-399, 1994.

7. Wirkner U, Voss H, Lichter P, Ansorge W and Pyerin W: The human gene (CSNK2A1) coding for the casein kinase II subunit alpha is located on chromosome 20 and contains tandemly arranged Alu repeats. Genomics 19: 257-265, 1994.

8. Ackermann K, Neidhart T, Gerber J, Waxmann A and Pyerin W: The catalytic subunit alpha' gene of human protein kinase $\mathrm{CK} 2$ (CSNK2A2): Genomic organization, promoter identification and determination of Ets1 as a key regulator. Mol Cell Biochem 274 91-101, 2005

9. Albertella MR, Jones H, Thomson W, Olavesen MG and Campbell RD: Localization of eight additional genes in the human major histocompatibility complex, including the gene encoding the casein kinase II beta subunit (CSNK2B). Genomics 36: 240-251, 1996.

10. Raaf J, Brunstein E, Issinger OG and Niefind K: The interaction of CK2alpha and CK2beta, the subunits of protein kinase CK2, requires CK2beta in a preformed conformation and is enthalpically driven. Protein Sci 17: 2180-2186, 2008.

11. Meggio F, Boldyreff BS, Marin O, Pinna LA and Issinger OG CK2: Role of the beta-subunit on the stability and specificity of the recombinant reconstituted holoenzyme. Eur J Biochem 204: 293-297, 1992.

12. Boldyreff BS, Meggio F, Pinna LA and Issinger O-G: Casein kinase-2 structure-function relationship: Creation of a set of mutants of the $\beta$ subunit that variably surrogate the wildtype $\beta$ subunit function. Biochem Biophys Res Commun 188: 228-234, 1992.

13. Rodriguez FA, Contreras C, Bolanos-Garcia V and Allende JE: Protein kinase $\mathrm{CK} 2$ as an ectokinase: The role of the regulatory CK2beta subunit. Proc Natl Acad Sci USA 105: 5693-5698, 2008.

14. Lolli G, Pinna LA and Battistutta R: Structural determinants of protein kinase CK2 regulation by autoinhibitory polymerization. ACS Chem Biol 7: 1158-1163, 2012

15. Lolli G, Naressi D, Sarno S and Battistutta R: Characterization of the oligomeric states of the CK2 alpha2beta 2 holoenzyme in solution. Biochem J 474: 2405-2416, 2017.

16. Raaf J, Guerra B, Neundorf I, Bopp B, Issinger OG, Jose J, Pietsch $\mathrm{M}$ and Niefind $\mathrm{K}$ : First structure of protein kinase CK2 catalytic subunit with an effective CK2 $\beta$-competitive ligand. ACS Chem Biol 8: 901-907, 2013.

17. Raaf J, Bischoff N, Klopffleisch K, Brunstein E, Olsen BB, Vilk G, Litchfield DW, Issinger OG and Niefind K: Interaction between $\mathrm{CK} 2 \alpha$ and $\mathrm{CK} 2 \beta$, the subunits of protein kinase $\mathrm{CK} 2$ : Thermodynamic contributions of key residues on the CK2 $\alpha$ surface. Biochemistry 50: 512-522, 2011.
18. Heriche JK, Lebrin F, Rabilloud T, LeRoy D, Chambaz EM and Goldberg Y: Regulation of protein phosphatase $2 \mathrm{~A}$ by direct interaction with casein kinase 2alpha. Science 276: 952-955, 1997.

19. Lüscher B and Litchfield DW: Biosynthesis of casein kinase II in lymphoid cell lines. Eur J Biochem 220: 521-526, 1994.

20. Guerra B, Siemer S, Boldyreff B and Issinger OG: Protein kinase CK2: Evidence for a protein kinase CK $2 \beta$ subunit fraction, devoid of the catalytic CK $2 \alpha$ subunit, in mouse brain and testicles. FEBS Lett 462: 353-357, 1999.

21. Trembley JH, Wang G, Unger G, Slaton J and Ahmed K: CK2: A key player in cancer biology. Cell Mol Life Sci 66: 1858-1867, 2009.

22. Benveniste EN, Gray GK and McFarland BC: Protein kinase CK2 and dysregulated oncogenic inflammatory signaling pathways Protein kinase CK2 cellular function in normal and disease states Springer e-book, 2015

23. Okur V, Cho MT, Henderson L, Retterer K, Schneider M, Sattler S, Niyazov D, Azage M, Smith S, Picker J, et al: De novo mutations in CSNK2A1 are associated with neurodevelopmental abnormalities and dysmorphic features. Hum Genet 135: 699-705, 2016.

24. Owen CI, Bowden R, Parker MJ, Patterson J, Patterson J, Price S, Sarkar A, Castle B, Deshpande C, Splitt M, et al: Extending the phenotype associated with the CSNK2A1-related Okur-Chung syndrome-A clinical study of 11 individuals. Am J Med Genet A $176: 1108-1114,2018$.

25. Trinh J, Huning I, Budler N, Hingst V, Lohmann $\mathrm{K}$ and Gillessen-Kaesbach G: A novel de novo mutation in CSNK2A1: Reinforcing the link to neurodevelopmental abnormalities and dysmorphic features. J Hum Genet 62: 1005-1006, 2017.

26. Lou DY, Dominguez I, Toselli P, Landesman-Bollag E, O'Brien C and Seldin DC: The alpha catalytic subunit of protein kinase $\mathrm{CK} 2$ is required for mouse embryonic development. Mol Cell Biol 28: 131-139, 2008.

27. Buchou T, Vernet M, Blond O, Jensen HH, Pointu H, Olsen BB, Cochet $\mathrm{C}$, Issinger $\mathrm{OG}$ and Boldyreff $\mathrm{B}$ : Disruption of the regulatory $b$ subunit of protein kinase $C K 2$ in mice leads to a cell-autonomous defect and early embryonic lethality. Mol Cell Biol 23: 908-915, 2003.

28. Xu X, Toselli PA, Russell LD and Seldin DC: Globozoospermia in mice lacking the casein kinase II a' catalytic subunit. Nat Genet 23: 118-121, 1999.

29. Götz C and Montenarh M: Protein kinase CK2 in development and differentiation. Biomed Rep 6: 127-133, 2016.

30. Niefind K, Pütter M, Guerra B, Issinger OG and Schomburg D: CTP plus water mimic ATP in the active site of protein kinase CK2. Nat Struct Biol 6: 1100-1103, 1999.

31. Lin WJ, Tuazon PT and Traugh JA: Characterization of the catalytic subunit of casein kinase II expressed in Escherichia coli and regulation of activity. J Biol Chem 266: 5664-5669, 1991.

32. Guerra B: Protein kinase CK 2 subunits are positive regulators of AKT kinase. Int J Oncol 28: 685-693, 2006.

33. Shehata M, Schnabl S, Demirtas D, Hilgarth M, Hubmann R, Ponath E, Badrnya S, Lehner C, Hoelbl A, Duechler M, et al: Reconstitution of PTEN activity by CK 2 inhibitors and interference with the PI3-K/Akt cascade counteract the antiapoptotic effect of human stromal cells in chronic lymphocytic leukemia. Blood 116: 2513-2521, 2010.

34. Wang S and Jones KA: CK2 controls the recruitment of Wnt regulators to target genes in vivo. Curr Biol 16: 2239-2244, 2006.

35. Gao Y and Wang HY: Casein kinase 2 Is activated and essential for Wnt/beta-catenin signaling. J Biol Chem 281: 18394-18400, 2006.

36. Ponce DP, Yefi R, Cabello P, Maturana JL, Niechi I, Silva E, Galindo M, Antonelli M, Marcelain K, Armisen R and Tapia JC: CK2 functionally interacts with AKT/PKB to promote the $\beta$-catenin-dependent expression of survivin and enhance cell survival. Mol Cell Biochem 356: 127-132, 2011.

37. Ponce DP, Maturana JL, Cabello P, Yefi R, Niechi I, Silva E, Armisen R, Galindo M, Antonelli M and Tapia JC: Phosphorylation of AKT/PKB by CK2 is necessary for the AKT-dependent up-regulation of $\beta$-catenin transcriptional activity. J Cell Physiol 226: 1953-1959, 2011.

38. Götz C and Montenarh M: Protein kinase CK2 in the ER stress response. Ad Biological Chemistry 3A: 1-5, 2013.

39. Montenarh M: Protein kinase CK2 in DNA damage and repair. Transl Cancer Res 5: 49-63, 2016.

40. Cozza G, Pinna LA and Moro S: Protein kinase CK2 inhibitors: A patent review. Expert Opin Ther Pat 22: 1081-1097, 2012 
41. Cozza G: The development of CK2 inhibitors: From traditional pharmacology to in silico rational drug design. Pharmaceuticals (Basel) 10: 26, 2017.

42. Prudent $\mathrm{R}$ and Cochet $\mathrm{C}$ : New protein kinase CK2 inhibitors: Jumping out of the catalytic box. Chem Biol 16: 112-120, 2009.

43. Bollacke A, Nienberg C, Borgne ML and Jose J: Toward selective CK2alpha and CK2alpha' inhibitors: Development of a novel whole-cell kinase assay by Autodisplay of catalytic CK2alpha'. J Pharm Biomed Anal 121: 253-260, 2016.

44. Battistutta R, Sarno S, De Moliner E, Papinutto E, Zanotti G and Pinna LA: The replacement of ATP by the competitive inhibitor emodin induces conformational modifications in the catalytic site of protein kinase CK2. J Biol Chem 275: 29618-29622, 2000.

45. Battistutta R, De Moliner E, Sarno S, Zanotti G and Pinna LA Structural features underlying selective inhibition of protein kinase CK2 by ATP site-directed tetrabromo-2-benzotriazole. Protein Sci 10: 2200-2206, 2001.

46. Pagano MA, Bain J, Kazimierczuk Z, Sarno S, Ruzzene M Di Maira G, Elliott M, Orzeszko A, Cozza G, Meggio F and Pinna LA: The selectivity of inhibitors of protein kinase CK2. An update. Biochem J 415: 353-365, 2008.

47. Sarno S, De Moliner E, Ruzzene M, Pagano MA, Battistutta R, Bain J, Fabbro D, Schoepfer J, Elliott M, Furet P, et al: Biochemical and three-dimensional-structural study of the specific inhibition of protein kinase CK2 by [5-oxo-5,6-dihydroindolo-(1,2-a)quinazolin-7-yl]acetic acid (IQA). Biochem J 374 639-646, 2003 .

48. Sarno S, Reddy H, Meggio F, Ruzzene M, Davies SP Donella-Deana A, Shugar D and Pinna LA: Selectivity of 4,5,6,7-tetrabromobenzotriazole, an ATP site-directed inhibitor of protein kinase CK2 ('casein kinase-2'). FEBS Lett 496: 44-48, 2001.

49. Pierre F, Chua PC, O'Brien SE, Siddiqui-Jain A, Bourbon P, Haddach M, Michaux J, Nagasawa J, Schwaebe MK, Stefan E, et al: Discovery and SAR of 5-(3-chlorophenylamino) benzo[c] $[2,6]$ naphthyridine-8-carboxylic acid (CX-4945), the first clinical stage inhibitor of protein kinase CK2 for the treatment of cancer. J Med Chem 54: 635-654, 2011.

50. Siddiqui-Jain A, Drygin D, Streiner N, Chua P, Pierre F, O'Brien SE, Bliesath J, Omori M, Huser N, Ho C, et al: CX-4945, an orally bioavailable selective inhibitor of protein kinase CK2, inhibits prosurvival and angiogenic signaling and exhibits antitumor efficacy. Cancer Res 70: 10288-10298, 2010.

51. Lee JY, Yun JS, Kim WK, Chun HS, Jin H, Cho S and Chang JH Structural basis for the selective inhibition of Cdc2-like kinases by CX-4945. Biomed Res Int 2019: 6125068, 2019.

52. Chua MM, Ortega CE, Sheikh A, Lee M, Abdul-Rassoul H, Hartshorn KL and Dominguez I: CK2 in cancer: Cellular and biochemical mechanisms and potential therapeutic target. Pharmaceuticals (Basel) 10: 18, 2017.

53. Faust M, Jung M, Günther J, Zimmermann R and Montenarh M: Localization of individual subunits of protein kinase CK2 to the endoplasmic reticulum and to the Golgi apparatus. Mol Cell Biochem 227: 73-80, 2001

54. Faust M, Schuster N and Montenarh M: Specific binding of protein kinase CK2 catalytic subunits to tubulin. FEBS Letters 462: 51-56, 1999.

55. Faust M, Günther J, Morgenstern E, Montenarh M and Götz C: Specific localization of the catalytic subunits of protein kinase CK2 at the centrosomes. Cell Mol Life Sci 59: 2155-2164, 2002.

56. Faust $\mathrm{M}$ and Montenarh M: Subcellular localization of protein kinase CK2: A key to its function? Cell Tissue Res 301: 329-340, 2000

57. Montenarh M and Götz C: Ecto-protein kinase CK2, the neglected form of CK2 (review). Biomed Rep 8: 307-313, 2018.

58. Suhas KS, Parida S, Gokul C, Srivastava V, Prakash E, Chauhan S, Singh TU, Panigrahi M, Telang AG and Mishra SK: Casein kinase 2 inhibition impairs spontaneous and oxytocin-induced contractions in late pregnant mouse uterus. Exp Physiol 103: 621-628, 2018

59. Gil C, Falques A, Sarro E, Cubi R, Blasi J, Aguilera J and Itarte E: Protein kinase CK2 associates to lipid rafts and its pharmacological inhibition enhances neurotransmitter release. FEBS Lett 585: 414-420, 2010.

60. Hernandez CM and Richards JR: Physiology, sodium channels. StatPearls Publishing 2020

61. Savio-Galimberti E, Gollob MH and Darbar D: Voltage-gated sodium channels: Biophysics, pharmacology, and related channelopathies. Front Pharmacol 3: 124, 2012.
62. Brachet A, Leterrier C, Irondelle M, Fache MP, Racine V, Sibarita JB, Choquet D and Dargent B: Ankyrin G restricts ion channel diffusion at the axonal initial segment before the establishment of the diffusion barrier. J Cell Biol 191: 383-395, 2010.

63. Grubb MS and Burrone J: Building and maintaining the axon initial segment. Curr Opin Neurobiol 20: 481-488, 2010.

64. Xu M and Cooper EC: An Ankyrin-G N-terminal gate and protein kinase CK2 dually regulate binding of voltage-gated sodium and KCNQ2/3 potassium channels. J Biol Chem 290: 16619-16632, 2015.

65. Bréchet A, Fache MP, Brachet A, Ferracci G, Baude A, Irondelle M, Pereira S, Leterrier C and Dargent B: Protein kinase CK2 contributes to the organization of sodium channels in axonal membranes by regulating their interactions with ankyrin G. J Cell Biol 183: 1101-1114, 2008.

66. Giraldez T, Rojas P, Jou J, Flores C and Alvarez de la Rosa D: The epithelial sodium channel delta-subunit: New notes for an old song. Am J Physiol Renal Physiol 303: F328-F338, 2012.

67. Baines D: Kinases as targets for ENaC regulation. Curr Mol Pharmacol 6: 50-64, 2013.

68. Shi HK, Asher C, Yung YV, Kligman L, Reuveny E, Seger R and Garty H: Casein kinase 2 specifically binds to and phosphorylates the carboxy termini of ENaC subunits. Eur J Biochem 269: 4551-4558, 2002

69. Bachhuber T, Almaca J, Aldehni F, Mehta A, Amaral MD, Schreiber R and Kunzelmann K: Regulation of the epithelial Na+ channel by protein kinase CK2. J Biol Chem 283: 13225-13232, 2008.

70. Hanukoglu I and Hanukoglu A: Epithelial sodium channel $(\mathrm{ENaC})$ family: Phylogeny, structure-function, tissue distribution, and associated inherited diseases. Gene 579: 95-132, 2016.

71. Berman JM, Mironova E and Stockand JD: Physiological regulation of the epithelial $\mathrm{Na}+$ channel by casein kinase II. Am J Physiol Renal Physiol 314: F367-F372, 2017.

72. Wulff H, Castle NA and Pardo LA: Voltage-gated potassium channels as therapeutic targets. Nat Rev Drug Discov 8: 982-1001, 2009.

73. Misonou H: Precise localizations of voltage-gated sodium and potassium channels in neurons. Dev Neurobiol 78: 271-282, 2018

74. Lezmy J, Lipinsky M, Khrapunsky Y, Patrich E, Shalom L, Peretz A, Fleidervish IA and Attali B: M-current inhibition rapidly induces a unique CK2-dependent plasticity of the axon initial segment. Proc Natl Acad Sci USA 114: E10234-E10243, 2017.

75. Kang S, Xu M, Cooper EC and Hoshi N: Channel anchored protein kinase CK2 and protein phosphatase 1 reciprocally regulate KCNQ2-containing M-channels via phosphorylation of calmodulin. J Biol Chem 289: 11536-11544, 2014.

76. Jentsch TJ: Neuronal KCNQ potassium channels: Physiology and role in disease. Nat Rev Neurosci 1: 21-30, 2000.

77. Greene DL and Hoshi N: Modulation of Kv7 channels and excitability in the brain. Cell Mol Life Sci 74: 495-508, 2017.

78. Kshatri AS, Gonzalez-Hernandez A and Giraldez T: Physiological roles and therapeutic potential of $\mathrm{Ca}^{2+}$ activated potassium channels in the nervous system. Front Mol Neurosci 11: 258, 2018

79. Meggio F, Boldyreff BS, Marin O, Marchiori F, Perich JW, Issinger OG and Pinna LA: The effect of polylysine on CK-2 activity is influenced by both the structure of the protein/peptide substrates and subunit composition of the enzyme. Eur J Biochem 205: 939-945, 1992.

80. Meggio F, Brunati AM and Pinna LA: Polycation-dependent, $\mathrm{Ca} 2+-$ antagonized phosphorylation of calmodulin by casein kinase- 2 and a spleen tyrosine protein kinase. FEBS Lett 215: 241-246, 1987.

81. Sacks DB, Davis HW, Crimmins DL and McDonald JM: Insulin-stimulated phosphorylation of calmodulin. Biochem J 286: 211-216, 1992

82. Maingret F, Coste B, Hao J, Giamarchi A, Allen D, Crest M, Litchfield DW, Adelman JP and Delmas P: Neurotransmitter modulation of small-conductance $\mathrm{Ca} 2+$-activated $\mathrm{K}+$ channels by regulation of Ca2+ gating. Neuron 59: 439-449, 2008.

83. Bildl W, Strassmaier T, Thurm H, Andersen J, Eble S, Oliver D, Knipper M, Mann M, Schulte U, Adelman JP and Fakler B: Protein kinase CK2 is coassembled with small conductance $\mathrm{Ca}^{2+}$-activated $\mathrm{K}^{+}$channels and regulates channel gating. Neuron 43: 847-858, 2004.

84. Allen D, Fakler B, Maylie J and Adelman JP: Organization and regulation of small conductance $\mathrm{Ca} 2+$-activated $\mathrm{K}+$ channel multiprotein complexes. J Neurosci 27: 2369-2376, 2007. 
85. Pallas DC, Shahrik LK, Martin BL, Jaspers S, Miller TB, Brautigan DL and Roberts TM: Polyoma small and middle $\mathrm{T}$ antigens and SV40 small $\mathrm{t}$ antigen form stable complexes with protein phosphatase 2A. Cell 60: 167-176, 1990.

86. Zhang M, Meng XY, Cui M, Pascal JM, Logothetis DE and Zhang JF: Selective phosphorylation modulates the PIP2 sensitivity of the CaM-SK channel complex. Nat Chem Biol 10 : 753-759, 2014

87. Stocker M, Krause M and Pedarzani P: An apamin-sensitive $\mathrm{Ca} 2+$-activated $\mathrm{K}+$ current in hippocampal pyramidal neurons. Proc Natl Acad Sci USA 96: 4662-4667, 1999.

88. Jiang ZS, Srisakuldee w, Soulet F, Bouche G and Kardami E: Non-angiogenic FGF-2 protects the ischemic heart from injury, in the presence or absence of reperfusion. Cardiovasc Res 62 : 154-166, 2004.

89. Li X, Hu H, Wang Y, Xue M, Li X, Cheng W, Xuan Y, Yin J, Yang $\mathrm{N}$ and Yan S: Valsartan Upregulates Kir2.1 in Rats Suffering from Myocardial Infarction via Casein Kinase 2. Cardiovasc Drugs Ther 29: 209-218, 2015.

90. Stocker M and Pedarzani P: Differential distribution of three $\mathrm{Ca}(2+)$-activated $\mathrm{K}(+)$ channel subunits, SK1, SK2, and SK3, in the adult rat central nervous system. Mol Cell Neurosci 15: 476-493, 2000.

91. Xia XM, Fakler B, Rivard A, Wayman G, Johnson-Pais T, Keen JE, Ishii T, Hirschberg B, Bond CT, Lutsenko S, et al: Mechanism of calcium gating in small-conductance calcium-activated potassium channels. Nature 395: 503-507, 1998.

92. Brehme H, Kirschstein T, Schulz R and Kohling R: In vivo treatment with the casein kinase 2 inhibitor 4,5,6,7-tetrabromotriazole augments the slow afterhyperpolarizing potential and prevents acute epileptiform activity. Epilepsia 55: 175-183, 2013

93. Bajorat R, Porath K, Kuhn J, Gossla E, Goerss D, Sellmann T, Köhling R and Kirschstein T: Oral administration of the casein kinase 2 inhibitor TBB leads to persistent $\mathrm{KCa} 2.2$ channel up-regulation in the epileptic CA1 area and cortex, but lacks anti-seizure efficacy in the pilocarpine epilepsy model. Epilepsy Res 147: 42-50, 2018

94. Schulze F, Muller S, Guli X, Schumann L, Brehme H, Riffert T, Rohde M, Goerss D, Rackow S, Einsle A, Kirschstein T and Kohling R: CK2 inhibition prior to status epilepticus persistently enhances $\mathrm{K}_{\mathrm{Ca}} 2$ function in CA1 which slows down disease progression. Front Cell Neurosci 14: 33, 2020.

95. Clapham DE: Calcium signaling. Cell 131: 1047-1058, 2007.

96. Afzal M, Kren BT, Naveed AK, Trembley JH and Ahmed K: Protein kinase CK2 impact on intracellular calcium homeostasis in prostate cancer. Mol Cell Biochem 470: 131-143, 2020.

97. Pankratov Y and Lalo U: Calcium permeability of ligand-gated Ca2+ channels. Eur J Pharmacol 739: 60-73, 2014.

98. Prakriya M and Lewis RS: Store-operated calcium channels. Physiol Rev 95: 1383-1436, 2015.

99. Zamponi GW, Striessnig J, Koschak A and Dolphin AC: The physiology, pathology, and pharmacology of voltage-gated calcium channels and their future therapeutic potential. Pharmacol Rev 67: 821-870, 2015.

100.Zamponi GW: A crash course in calcium channels. ACS Chem Neurosci 8: 2583-2585, 2017.

101. Catterall WA: Structure and regulation of voltage-gated Ca2+ channels. Annu Rev Cell Dev Biol 16: 521-555, 2000 .

102. Christel $\mathrm{C}$ and Lee $\mathrm{A}$ : Ca2+-dependent modulation of voltage-gated $\mathrm{Ca} 2+$ channels. Biochim Biophys Acta 1820 $1243-1252,2012$

103. Xu L, Sun L, Xie L, Mou S, Zhang D, Zhu J and Xu P: Advance in L-type calcium channel structures, functions and molecular modeling. Curr Med Chem: Jul 14, 2020, Doi: 10.2174/0929867 327666200714154059 Online ahead of print

104. Weiss S, Oz S, Benmocha A and Dascal N: Regulation of cardiac L-type $\mathrm{Ca}^{2+}$ channel CaV1.2 via the $\beta$-adrenergic-cAMP-protein kinase A pathway: Old dogmas, advances, and new uncertainties. Circ Res 113: 617-631, 2013.

105. Hulme JT, Lin TW, Westenbroek RE, Scheuer T and Catterall WA: Beta-adrenergic regulation requires direct anchoring of PKA to cardiac CaV1.2 channels via a leucine zipper interaction with A kinase-anchoring protein 15. Proc Natl Acad Sci USA 100: 13093-13098, 2003.

106. De Jongh KS, Murphy BJ, Colvin AA, Hell JW, Takahashi M and Catterall WA: Specific phosphorylation of a site in the full-length form of the alpha 1 subunit of the cardiac L-type calcium channel by adenosine 3',5'-cyclic monophosphate-dependent protein kinase. Biochemistry 35: 10392-10402, 1996.
107. Peterson BZ, DeMaria CD, Adelman JP and Yue DT: Calmodulin is the $\mathrm{Ca} 2+$ sensor for $\mathrm{Ca} 2+-$-dependent inactivation of L-type calcium channels. Neuron 22: 549-558, 1999.

108. Fuller MD, Emrick MA, Sadilek M, Scheuer T and Catterall WA: Molecular mechanism of calcium channel regulation in the fight-or-flight response. Sci Signal 3: ra70, 2010.

109. Fu Y, Westenbroek RE, Scheuer T and Catterall WA: Basal and $\beta$-adrenergic regulation of the cardiac calcium channel CaV1.2 requires phosphorylation of serine 1700. Proc Natl Acad Sci USA 111: 16598-16603, 2014.

110. Fu Y, Westenbroek RE, Scheuer $\mathrm{T}$ and Catterall WA: Phosphorylation sites required for regulation of cardiac calcium channels in the fight-or-flight response. Proc Natl Acad Sci USA 110: 19621-19626, 2013.

111. Kashihara T, Nakada T, Kojima K, Takeshita T and Yamada M: Angiotensin II activates $\mathrm{CaV} 1.2 \mathrm{Ca}^{2+}$ channels through $\beta$-arrestin 2 and casein kinase 2 in mouse immature cardiomyocytes. J Physiol 595: 4207-4225, 2017.

112. Hauck L, Harms C, Rohne J, Gertz K, Dietz R, Endres M and von HR: Protein kinase CK2 links extracellular growth factor signaling with the control of p27(Kip1) stability in the heart. Nat Med 14: 315-324, 2008

113. Gomez-Ospina N, Tsuruta F, Barreto-Chang $\mathrm{O}, \mathrm{Hu} \mathrm{L}$ and Dolmetsch R: The $\mathrm{C}$ terminus of the L-type voltage-gated calcium channel $\mathrm{Ca}(\mathrm{V}) 1.2$ encodes a transcription factor. Cell 127: 591-606, 2006

114. Feng R, Xu J, Minobe E, Kameyama A, Yang L, Yu L, Hao L and Kameyama M: Adenosine triphosphate regulates the activity of guinea pig Cavl.2 channel by direct binding to the channel in a dose-dependent manner. Am J Physiol Cell Physiol 306 C856-C863, 2014.

115. Braun M, Ramracheya R, Bengtsson M, Zhang Q, Karanauskaite J, Partridge C, Johnson PR and Rorsman P: Voltage-gated ion channels in human pancreatic beta-cells: Electrophysiological characterization and role in insulin secretion. Diabetes 57: 1618-1628, 2008

116. Yang SN and Berggren PO: The role of voltage-gated calcium channels in pancreatic beta-cell physiology and pathophysiology. Endocr Rev 27: 621-676, 2006.

117. Scheuer R, Philipp SE, Becker A, Nalbach L, Ampofo E, Montenarh $\mathrm{M}$ and Götz C: Protein kinase CK2 controls $\mathrm{CaV} 2.1$-dependent calcium currents and insulin release in pancreatic $\beta$-cells. Int J Mol Sci 21: 4668, 2020.

118. Lolli G, Cozza G, Mazzorana M, Tibaldi E, Cesaro L, Donella-Deana A, Meggio F, Venerando A, Franchin C, Sarno S, et al: Inhibition of protein kinase CK2 by flavonoids and tyrphostins. A structural insight. Biochemistry 51: 6097-6107, 2012.

119. Catterall WA: Voltage-gated calcium channels. Cold Spring Harb Perspect Biol 3: a003947, 2011.

120. Kahle JJ, Gulbahce N, Shaw CA, Lim J, Hill DE, Barabási AL and Zoghbi HY: Comparison of an expanded ataxia interactome with patient medical records reveals a relationship between macular degeneration and ataxia. Hum Mol Genet 20: 510-527, 2011

121. Rettig J, Sheng ZH, Kim DK, Hodson CD, Snutch TP and Catterall WA: Isoform-specific interaction of the alpha1A subunits of brain $\mathrm{Ca} 2+$ channels with the presynaptic proteins syntaxin and SNAP-25. Proc Natl Acad Sci USA 93: 7363-7368, 1996.

122. Hilfiker S, Pieribone VA, Nordstedt C, Greengard P and Czernik AJ: Regulation of synaptotagmin I phosphorylation by multiple protein kinases. J Neurochem 73: 921-932, 1999.

123. Castillo MA, Ghose S, Tamminga CA and Ulery-Reynolds PG: Deficits in syntaxin 1 phosphorylation in schizophrenia prefrontal cortex. Biol Psychiatry 67: 208-216, 2010.

124. Hwang TC, Yeh JT, Zhang J, Yu YC, Yeh HI and Destefano S: Structural mechanisms of CFTR function and dysfunction. J Gen Physiol 150: 539-570, 2018.

125. Fajac I and De BK: New horizons for cystic fibrosis treatment Pharmacol Ther 170: 205-211,2017.

126. Csanady L, Vergani P and Gadsby DC: Structure, gating, and regulation of the CFTR anion channel. Physiol Rev 99: 707-738, 2019.

127. Cesaro L, Marin O, Venerando A, Donella-Deana A and Pinna LA: Phosphorylation of cystic fibrosis transmembrane conductance regulator (CFTR) serine-511 by the combined action of tyrosine kinases and CK2: The implication of tyrosine-512 and phenylalanine-508. Amino Acids 45: 1423-1429, 2013. 
128. Luz S, Kongsuphol P, Mendes AI, Romeiras F, Sousa M Schreiber R, Matos P, Jordan P, Mehta A, Amaral MD, et al: Contribution of casein kinase 2 and spleen tyrosine kinase to CFTR trafficking and protein kinase A-induced activity. Mol Cell Biol 31: 4392-4404, 2011.

129. Mehta A: Cystic fibrosis as a bowel cancer syndrome and the potential role of CK2. Mol Cell Biochem 316: 169-175, 2008.

130. Pagano MA, Arrigoni G, Marin O, Sarno S, Meggio F, Treharne KJ, Mehta A and Pinna LA: Modulation of protein kinase CK2 activity by fragments of CFTR encompassing F508 may reflect functional links with cystic fibrosis pathogenesis. Biochemistry 47: 7925-7936, 2008.

131. Treharne KJ, Xu Z, Chen JH, Best OG, Cassidy DM, Gruenert DC, Hegyi P, Gray MA, Sheppard DN, Kunzelmann K and Mehta A: Inhibition of protein kinase CK2 closes the CFTR Cl channel, but has no effect on the cystic fibrosis mutant deltaF508-CFTR. Cell Physiol Biochem 24: 347-360, 2009.

132. Venerando A, Pagano MA, Tosoni K, Meggio F, Cassidy D, Stobbart M, Pinna LA and Mehta A: Understanding protein kinase CK2 mis-regulation upon F508del CFTR expression. Naunyn Schmiedebergs Arch Pharmacol 384: 473-488, 2011.

133. Pagano MA, Marin O, Cozza G, Sarno S, Meggio F, Treharne KJ, Mehta A and Pinna LA: Cystic fibrosis transmembrane regulator fragments with the Phe508 deletion exert a dual allosteric control over the master kinase CK2. Biochem J 426: 19-29, 2010.
134. Pinto MC, Schreiber R, Lerias J, Ousingsawat J, Duarte A, Amaral M and Kunzelmann K: Regulation of TMEM16A by CK2 and its role in cellular proliferation. Cells 9: 1138, 2020.

135. Roosbeek S, Peelman F, Verhee A, Labeur C, Caster H, Lensink MF, Cirulli C, Grooten J, Cochet C, Vandekerckhove JL, et al: Phosphorylation by protein kinase CK2 modulates the activity of the ATP binding cassette A1 transporter. J Biol Chem 279: 37779-37788, 2004.

136. Bai X, Moraes TF and Reithmeier RAF: Structural biology of solute carrier (SLC) membrane transport proteins. Mol Membr Biol 34: 1-32, 2017.

137. Ibrahim SH, Turner MJ, Saint-Criq V, Garnett J, Haq IJ, Brodlie M, Ward C, Borgo C, Salvi M, Venerando A and Gray MA: CK2 is a key regulator of SLC4A2-mediated $\mathrm{Cl}-/ \mathrm{HCO}_{3}$ exchange in human airway epithelia. Pflugers Arch 469: 1073-1091, 2017.

138. Stolk M, Cooper E, Vilk G, Litchfield DW and Hammond JR: Subtype-specific regulation of equilibrative nucleoside transporters by protein kinase CK2. Biochem J 386: 281-289, 2005. International (CC BY-NC-ND 4.0) License. 